\title{
Black locust (Robinia pseudoacacia L.) selection programmes in Hungary: a short review
}

\author{
Csiha, I. ${ }^{1}$, Keserü, Zs. ${ }^{1}$, Rásó, J. ${ }^{1}$ \& Rédei,K. ${ }^{2}$ \\ ${ }^{I}$ NARIC-Forest Research Institute (FRI), Experimental Station, Püspökladány, Hungary \\ ${ }^{2}$ NARIC-FRI\&HHPM Non-profit Ltd., Sárvár-Budapest \\ correspondence:keseruzs@erti.hu
}

\begin{abstract}
Summary: Black locust (Robinia pseudoacacia L.) was the first forest tree species introduced from North America to Europe, at the beginning of the $17^{\text {th }}$ century. Its unprecedented fast spread is due to its high-grade adaptability, drought-tolerance, abundant and frequent seed crop, excellent sprouting ability, fast growth and relatively high timber yield. Other advantages are, that it has scarcely any fungi or insect pests. This review is a short summary on black locust improvement in Hungary, giving guidance for specialists who are interested in black locust management.
\end{abstract}

Keywords: black locust (Robinia pseudoacacia L.), improvement, clones, varieties

\section{Introduction}

Hungary has got much experience in black locust growing, as it has been grown for 300 years in the country. The proportion of black locust stands in the total stocked area of forests amounts to $23 \%$ (460,000 ha), the growing stock of which is around 38 million $\mathrm{m}^{3}$. Being aware of its importance, forestry research in Hungary continues to deal with various aspects of black locust growing, with special regard to the energy crisis and to the global climate change harmful effects thanks to having some desirable characteristics of the tree species. The most important black locust growing regions in Hungary are located in the south and south-west Transdanubia (hill-ridges of Vas-Zala county, hill-ridges Somogy county), the plain between the rivers Danube and Tisza (Central Hungary) and north-east Hungary (Nyírség region) (Keresztesi, 1988)..

Black locust timber can be used by industry (mining, construction and furniture) or by agriculture sector (post and pole wood). Moreover, the black locust stands are the main basis for Hungarian apiculture and honey production. Black locust is also one of the most suitable tree species for establishing energy and environmental plantations. To provide for the development of a natural environment, forests together with agricultural fields, shelterbelts should create an integrated landscape. In this case, afforestation is useful for the development of both agriculture and forestry to improve the natural environment and living conditions of the population (Keresztesi, 1988, Rédei, 2000).

Of the fast-growing deciduous tree species of the world it is the black locust that is the third after the eucalyptus and hybrid poplars in forest stand establishments and man-made reforestations. At the moment the total area of black locust is globally about 2.5 million ha. In the near future there are two continents, where the fast spread of black locust can be expected. The first is the Asian continent, where China and South and North Korea, while in the European continent France, Turkey, Romania, Bulgaria and Germany may be the most prominent black locust growers.

\section{The results of the first black locust selection programme}

Since the introduction of black locust into Hungary this tree species has been closely associated with agriculture, and its wood could be utilized for many agricultural and domestic purposes. After World War II its importance changed because large-scale farms had less demand for wood and the timber industry was not willing to buy black locust wood. It was necessary to improve the quality of final products of black locust forests to meet the demands of consumers. Therefore, new cultivars had to be produced by breeding techniques and had to be introduced into the practical forestry use.

Breeding by crossing requires much work over several decades, as the black locust is a heterozygot tree species with many features of polygene character. The results of breeding are thus influenced by chance. Though the prominent Hungarian black locust breeder, F. Kopecky worked with a carefully elaborated breeding program, his investigations into the performance of different provenances did not fulfil early expectations, despite some promising results. Simultaneously with man-made crossings a new strategy of several stages started in the Hungarian Forest Research Institute in 1961 (Keresztesi,1983).

The breeding strategy aimed to improve the quality of black locust stands, which were considered to be separate provenances. In the best black locust stands tree groups of 
shipmast stem form, then plus trees were selected by B. Keresztesi and his colleagues. The offsprings of these selected trees were vegetatively propagated and were grouped together into varieties. Thus, varieties are mostly composed of several clones, but there are also some one-clone-varieties, too.

Grafts with shoots taken from plus trees were made and planting stocks were raised from them by green cuttings. The basic material produced in this way served as starting material with the help of a variety trial established in Gödöllö Arboretum of the Hungarian Forest Research Institute. The development of this trial has been continuing up to the present even in these days. The soil of this experiment area is a rusty brown forest soil developed over sand (Keresztesi, 1983,1988).

In the meantime breeding aims were enlarged by taking the demands of bee-keeping into consideration, such as the onset and length of flowering, while nectar yields were also considered and improved. Some trees selected abroad and others in Hungary that had been chosen by beekeepers for their excellent honey production were involved in this experiment.

The aim of the trial was to determine the heritable growth and quality features of cultivars selected from various parts of the country and abroad and to put them into comparison. For the time being this trial in Gödöllö Arboretum is covering 50 ha with 210 clones and varieties, respectively.

The main target of breeding is to improve the quality of stem, to increase the output of industrial wood. The results are evaluated by timber volume and its value at felling age. Even a small improvement in volume means a considerable increase in financial return. Based on timber volume at felling age the following cultivars may be assessed as best: 'Jászkiséri', 'Üllôi', 'Nyirségi', 'Kiskunsági', 'Kiscsalai' and 'Pénzesdombi'. Beside the varieties recommended for timber production as primary function, there are others that have been improved for honey production or energy production (Keresztesi, 1988).

At the moment 7 black locust varieties are approved by the competent Hungarian national office (heavily written):

Varieties and variety-candidates for high volume, high quality sawlog production are:

'Nyírségi', 'Kiskunsági', 'Jászkiséri', 'Pénzesdombi', 'Üllôi', 'Egylevelû', 'Kiscsalai', 'Röjtökmuzsaji' and 'Góri'.

Varieties and variety-candidates for pole and propproduction are:

'Zalai', 'Császártöltési', 'Szajki', 'Ricsikai', 'Váti-46', 'Appalachia'.

Varieties and variety-candidates for honey production are:

'Rózsaszín-AC', 'Debreceni-2', 'Halvány rózsaszinû', 'Debreceni 3-4', 'Mátyusi 1-3', 'Váti-46', 'Zalai', 'Kiskunsági', 'Császártöltési', 'Egylevelû'.

Varieties and variety candidates for fuelwood-production are:

'Jászkiséri'; 'Üllôi', 'Kiscsalai', 'Nyírségi', 'Góri', 'Röjtökmuzsaji' and 'Rózsaszín- $\boldsymbol{A} \boldsymbol{C}$ '.

Varieties and variety-candidates for fodder production are:

'Appalachia', 'Egylevelû', 'Gigant', 'Jászkiséri' and 'Kiskunsági'.

As it is evident from the enumeration, there are several multipurpose varieties. Varieties selected for honey production can be characterized by their long lasting flowering, by later onset of flowering than that of common black locust and by their better than average nectar yield.

Propagation of varieties was first planned by seedlings, but the seed orchards produced small quantities of seed. So it was necessary to develop techniques for vegetative propagation (with green cuttings, rootcuttings and micropropagation).

\section{A partly new black locust selection programme}

In Hungary the range of sites optimal for black locust growing is rather limited. Therefore, black locust growing is exercised often on sub-optimal sites. Possibilities for black locust growing are highly influenced by climatic conditions and extremes (temperature and precipitation), water supply and unfavourable soil conditions. In the lowlands, which are the most suitable regions for black locust production, annual precipitation is not more than $500 \mathrm{~mm}$, most of which is outside the growing season. Relative air humidity in July is usually between $20-50 \%$. Due to the filling up of basin-like lowlands in Hungary, site conditions are a mosaic, which changes even over small distances, causing widely differing growth potential for black locust plantations. For this reason, there are no large, contiguous areas of homogenous site quality for black locust, and its growth and productivity may be very variable within a large field. Therefore, the main aim of the new selection work coordinated by K. Rédei is to find and improve black locust clones, which perform good shape; provide good-quality wood material for industrial purposes, and which can adapt to the changed ecological conditions as well (Rédei, 2002, Rédei et al., 2002).

As a result of the new selection programme 12 black locust clones (' $K H 56 A 2 / 5$ ', 'KH 56A 2/6', 'MB12D', 'MB17D 4/1', 'CST 61A 3/1', 'MB15A 2/3', 'MB17D 3/4', 'PV 201E 2/1', 'PV 201E 2/3', 'PV 201E 3/4', 'PV 35B/2' and ' $P V$ 233A/2') have been improved over the last years at the Hungarian Forest Research Institute. Five clones (' $\mathrm{KH}$ 56A 2/5', 'MB17D 3/4', 'PV 201E 2/1', 'PV 35B/2' and ' $P V$ $233 A / 1$ ') have been registered as variety- candidate (Rédei et al., 2002, Rédei et al., 2008).

\section{Vegetative propagation of black locust - Propagation from root cuttings}

Black locust clonal varieties have to be propagated in vegetative way. In practical forestry the propagation by roots has proved successful. Vegetative propagated plants are produced from root cuttings or even pieces of root can be directly sown, too. In both cases the basic material for vegetative propagation can be derived from the gene bank of the experimental nursery owned by the Hungarian Forest Research Institute (Rédei et al., 2001).

Plants to be used as the basic material for root cutting production are produced from reproduction material from the gene bank. These plants are delivered to nurseries involved in production and then set out in a spacing of 30-40x80 cm to encourage the rich root crop. For 5 years these plants are lifted in every spring and by curtailing their roots, root cutting will 
Table 1: Stand characteristics of black locust clones and varieties at age of 6 years at Isaszeg (forest-steppe climate)

\begin{tabular}{|c|c|c|c|c|c|c|c|c|c|}
\hline \multirow[t]{2}{*}{ Clone name } & \multirow[t]{2}{*}{$\begin{array}{c}\text { Plot } \\
\text { number }\end{array}$} & \multirow[t]{2}{*}{$\begin{array}{l}\text { Height } \\
\text { (m) }\end{array}$} & \multirow[t]{2}{*}{$\begin{array}{l}\text { DBH } \\
(\mathrm{cm})\end{array}$} & \multirow[t]{2}{*}{$\begin{array}{l}\text { SFV } \\
(1-4)\end{array}$} & $\begin{array}{l}\text { Height } \\
\text { (m) }\end{array}$ & $\begin{array}{l}\mathrm{DBH} \\
(\mathrm{cm})\end{array}$ & $\begin{array}{c}\text { Mean tree } \\
\text { volume } \\
(\mathrm{m} 3)\end{array}$ & $\begin{array}{l}\text { Percentage } \\
\text { of survival } \\
\text { plants (\%) }\end{array}$ & $\begin{array}{l}\text { SFV } \\
(1-4)\end{array}$ \\
\hline & & & & & \multicolumn{5}{|c|}{ plot average values } \\
\hline \multirow{3}{*}{ R.p. 'Kiskunsági' } & 1 & 6.0 & 5.3 & 1.9 & \multirow{3}{*}{5.7} & \multirow{3}{*}{5.1} & \multirow{3}{*}{0.0094} & \multirow{3}{*}{85} & \multirow{3}{*}{1.8} \\
\hline & 23 & 6.3 & 5.5 & 1.8 & & & & & \\
\hline & 30 & 5.0 & 4.5 & 1.6 & & & & & \\
\hline \multirow{3}{*}{ R.p. 'Üllői' } & 3 & 5.4 & 4.8 & 1.8 & \multirow{3}{*}{5.5} & \multirow{3}{*}{4.9} & \multirow{3}{*}{0.0090} & \multirow{3}{*}{83} & \multirow{3}{*}{1.9} \\
\hline & 15 & 5.3 & 4.5 & 1.9 & & & & & \\
\hline & 24 & 5.7 & 5.0 & 1.9 & & & & & \\
\hline \multirow{3}{*}{ R.p. 'Homoki' ('MB17D3/4') } & 10 & 6.0 & 5.5 & 1.7 & \multirow{3}{*}{5.5} & \multirow{3}{*}{5.3} & \multirow{3}{*}{0.0098} & \multirow{3}{*}{82} & \multirow{3}{*}{1.8} \\
\hline & 25 & 5.0 & 5.1 & 1.9 & & & & & \\
\hline & $(10+25) / 2$ & 5.5 & 5.3 & 1.8 & & & & & \\
\hline \multirow{3}{*}{ Common black locust (control) } & 14 & 5.9 & 5.5 & 2.2 & \multirow{3}{*}{5.1} & \multirow{3}{*}{4.9} & \multirow{3}{*}{0.0088} & \multirow{3}{*}{82} & \multirow{3}{*}{2.3} \\
\hline & 21 & 4.9 & 4.6 & 2.3 & & & & & \\
\hline & 27 & 4.6 & 454 & 2.3 & & & & & \\
\hline
\end{tabular}

$\mathrm{H}=$ mean height of the trees; $\mathrm{DBH}=$ diameter at breast height $(\mathrm{d} 1.3)$; $\mathrm{SFV}=$ stem form value (1-4).

be raised and then replanted. In 5 years the plants used for root production must be replaced by new ones from the gene bank.

Planting material to be used for afforestation is raised by planting root cuttings in a spacing of $5-10 \times 80 \mathrm{~cm}$. The usual dimension of root cuttings is $8-10 \mathrm{~cm}$ in length and $5-8 \mathrm{~mm}$ in diameter. In case of direct sowing root-pieces of 3-4 cm are used. Roots have to be inserted into well-prepared soil in a drill of 8-10 $\mathrm{cm}$ depth with a distance between root pieces of 5-7 cm. With this spacing, 10-15 plants can be raised per running metre. All other roots can be used for further propagation. In general, plants are lifted in spring and that is the time when roots for propagation are collected. Normally this takes some 5 to 6 weeks, but if storage of cuttings before planting or sowing is unavoidable, they should be kept permanently moist. When propagating plants from root pieces, the appearance of plantlets can be expected 20-25 days after cutting. The average height of the one-year old plants is $1.2-1.5$ $\mathrm{m}$ (Rédei et al., 2001).

\section{Conclusion}

For some decades black locust has an increased attention in more and more countries for the following reason. The global climate changes and the energy crisis has stimulated research on relatively rapid growing, nitrogen-fixing trees such as black locust. This short review leads to the following conclusions: (1) selected black locust varieties can be grown well under semi-marginal site condition as well; (2) vegetative propagation method - root cuttings - have proved as a suitable mean in the field of black locust clonal selection; (3) by growing selected black locust varieties it is possible to increase significantly the stem quality (by $15-25 \%$ on average) (Table 1 ).
Black locust is already planted for many of its ecological benefits. Some studies have indicated that considerable genetic variation exists within the species (Bontgarten et al.,1991, Dengiz et. al., 2010, Dini-Papanastasi et. al., 2000, Dunlun et. al., 1995, Liesebach et al., 2004). Intensive single tree selection coupled with a successful vegetative propagation programme may lead to significant improvement for the species.

\section{Acknowledgements}

The authors would like to express their appreciation to the Korea Institute of Forest Science for its financial support to bring the join black locust improvement project to fruition.

\section{References}

Bongarten, B.C., Merkle, S.A. and Hanover, J.W. (1991): Genetically improved black locust for biomass production in shortrotation plantations. In: Energy from Biomass and Wastes XV (KLASS, D.L. ed.), Institute of Gas Technology, Chicago, IL. 391-409.

Dengiz, O., Gol, C., Sarioglu, F. E. and Edis, S. (2010): Parametric approach to land evaluation for forest plantation: A methodological study using GIS model. African Journal of Agricultural Research. 5 (12): 1482-1496.

Dini-Papanastasi, O. and Panetsos, C.P. (2000): Relation between growth and morphological traits and genetic parameters of Robinia pseudoacacia var. monophylla DC in northern Greece. Silvae Genet. (49): 37-44.

Dunlun, Z. , Zhenfen, Z. and Fangquan, W. (1995): Progress in clonal selection and breeding of black locust (Robinia pseudoacacia L.) In: Forest Tree Improvement in the Asia-Pacific Region (Xihuan Shen): China Forestry Publishing House, Beijing, 152-156. 
Keresztesi, B. (1983): Breeding and cultivation of black locust (Robinia pseudoacacia L.) in Hungary. Forest Ecology and Management. 6: 217-244.

Keresztesi, B. (Eds.) (1988): The Black Locust. Akadémiai Kiadó, Budapest.

Liesebach, H., Yang M. S.and Schneck, V. (2004): Genetic diversity and differentiation in a black locust (Robinia pseudoacacia L.) progeny test. Forest Genetics 11 (2): 151-161.

Rédei, K. (2000): The Role of Black Locust (Robinia pseudoacacia L.) in Establishing Wood Energy Plantation. Hungarian Agricultural Research. 9 (4): 4-7.
Rédei, K. (2002): Improvement of Black Locust (Rominia pseudoacacia L.) in Hungary. IUFRO Meeting on the Management of Fast Growing Plantations. Izmit, Turkey, Proceeding, 166-173.

Rédei, K., Ostváth-Bujtás, Z. and Balla, I. (2001): Propagation methods for black locust (Robinia pseudoacacia L.) improvement in Hungary. Journal of Forestry Research. 12 (4): 215-219.

Rédei, K., Ostváth-Bujtás, Z. and Balla, I. (2002): Clonal approaches to growing black locust (Rominia pseudoacacia) in Hungary: a review. Forestry. 75 (5): 548-552. 